\title{
COPPINSIELLA AND SEAWARDIELLA - TWO NEW GENERA OF THE XANTHORIOIDEAE (TELOSCHISTACEAE, LICHEN-FORMING ASCOMYCOTA)
}

\author{
S. Y. KondratyuK ${ }^{1}$, I. Kärnefelt ${ }^{2}$, L. LőKös ${ }^{3}$, J.-S. Hur ${ }^{4}$ and A. Thell ${ }^{2}$ \\ ${ }^{1}$ M. H. Kholodny Institute of Botany \\ Tereshchenkivska str.2, 01004 Kiev,_Ukraine; E-mail:ksya_net@ukr.net \\ ${ }^{2}$ Biological Museum, Lund University \\ Box 117, SE-221 00 Lund, Sweden; E-mail: arne.thell@biol.lu.se \\ ${ }^{3}$ Department of Botany, Hungarian Natural History Museum \\ H-1431 Budapest, Pf. 137, Hungary; E-mail: lokos.laszlo@nhmus.hu \\ ${ }^{4}$ Korean Lichen Research Institute, Sunchon National University \\ Sunchon 540-742, Republic of Korea; E-mail: jshur1@sunchon.ac.kr
}

(Received 18 June, 2018; Accepted 18 July, 2018)

The genera Coppinsiella and Seawardiella are described based on the combined phylogenetic analysis from ITS nrDNA, 28S nrLSU and $12 \mathrm{~S} \mathrm{mtSSU}$ sequences. The affinities of the new genera Orientophila, Athallia, Flavoplaca and Calogaya are discussed. The former Caloplaca lobulata group (or 'Xanthoria lobulata-Gruppe' sensu Steiner et Poelt 1982) found to be positioned in the Calogaya clade based on ITS phylogeny while after a three gene phylogeny (based on ITS nrDNA, nrLSU and mtSSU sequences) two species (i.e.: Seawardiella lobulata and described as new S. tasmaniensis) were located in the Seawardiella clade of the Xanthorioideae. Three other species (i.e. Lazarenkoella zoroasteriorum, L. persica and L. polycarpoides) were positioned in the Lazarenkoella-clade of the Brownlielloideae. The position of all species of the Calogaya clade (after ITS phylogeny) should be re-evaluated based on three gene phylogeny from ITS nrDNA, nrLSU and mtSSU sequences. The new species Seawardiella tasmaniensis is described, illustrated and compared with closely related taxa.

New combinations are suggested for eight taxa (i.e. Athallia inconnexa (for Lecanora inconnexa Nyl.), Calogaya safavidiorum (for Caloplaca safavidiorum S. Y. Kondr., in Kondratyuk et al.), Coppinsiella orbicularis stat. et comb. nov. (for Caloplaca substerilis subsp. orbicularis M. Haji Moniri, Vondrák et Malíček), Coppinsiella substerilis (for Caloplaca substerilis Vondrák, Palice et van den Boom, in Vondrák et al.), Coppinsiella ulcerosa (for Caloplaca ulcerosa Coppins et P. James), Lazarenkoella persica (for Xanthoria polycarpoides var. persica J. Steiner); Lazarenkoella polycarpoides (for Xanthoria polycarpoides J. Steiner), and Seawardiella lobulata (for Lecanora lobulata Flörke)).

Key words: combined phylogenetic analysis, Lazarenkoella, new genera, Xanthorioideae

\section{INTRODUCTION}

More than 100 genera in the four subfamilies Xanthorioideae, Caloplacoideae, Teloschistoideae and Brownlielloideae in the Teloschistaceae have been separated based on a three gene phylogeny, i.e. on ITS nrDNA, nrLSU 
and $\mathrm{mtSSU}$ sequences (Kondratyuk et al. 2017a, 2018a, b). Among the subfamilies the Xanthorioideae includes the highest number of genera, i.e. 39 (Kondratyuk et al. 2017a, 2018a). Several special papers on the molecular phylogeny of the representatives of the Xanthorioideae have been published (Fedorenko et al. 2009, 2012, Arup et al. 2013, Kondratyuk et al. 2014, 2015a, b, 2017a), while some monophyletic clades still wait for taxonomic treatment. The aim of this paper is the publication of the new genera Coppinsiella and Seawardiella, which apparently correspond with two branches of the phylogenetic tree of the Xanthorioideae known as the 'Caloplaca ulcerosa' group and the former 'Calogaya lobulata' group. The position of members of the Calogaya clade based on ITS phylogeny is furthermore discussed.

\section{MATERIAL AND METHODS}

The morphology was studied with a dissecting microscope (Nikon SMZ 645, Nikon, Tokyo, Japan), whereas anatomical structures were studied with an Olympus BX51 light microscope with an Olympus DP-Soft photo program (in MSK-L) and Nikon Eclipse E200 (Nikon, Tokyo, Japan), and Zeiss Scope A1 (Carl Zeiss, Oberkochen, Germany) with a digital camera AxioCam ERc 5s (in KoLRI).

Sequenced specimens in the genera Coppinsiella, Seawardiella and Lazarenkoella are listed below (Table 1). Data on ITS nrDNA, nrLSU and mtSSU of specimens of the other genera of the Xanthorioideae included in the phylogenetic trees have been provided in a previous paper (Kondratyuk et al. 2017a).

Small fragments were extracted using standard methods described in Fedorenko et al. (2009). Three gene regions were selected for the study, ITS nrDNA, nrLSU and mtSSU, using the primers ITS1 and ITS4 (Fedorenko et al. 2009), ITS1F (Gardes and Bruns 1993), LR5 (Vilgalys and Hester 1990), and $\mathrm{mtSSU1}-\mathrm{mtSSU} 3 \mathrm{R}$ and $\mathrm{mtSSU} 2 \mathrm{R}$ (Zoller et al. 1999). The phylogenetic analyses of the manually aligned sequences were performed with PAUP version $4.0 \mathrm{~b}$ (Swofford 2003). Trees were calculated using the general heuristic search option, maximising the number of saved trees to 1,000, whereas gaps were treated as missing characters.

\section{RESULTS}

Coppinsiella S. Y. Kondr. et L. Lőkös, gen. nov.

MycoBank no.: MB 827054

Similar to the genus Athallia, but differs in a more developed thallus, often with characteristic crater-like soralia and zeorine apothecia.

Type species: Coppinsiella ulcerosa (Coppins et P. James) S. Y. Kondr. et L. Lőkös. 










Thallus crustose, very thin, film-like, more or less continuous to endolithic or endophloeodal, and minutely squamulose, grey to whitish, $\mathrm{K}$-, or yellowish and $\mathrm{K}+$ violet; soralia scattered, hardly distinct or from welldeveloped, immersed, crater-like to irregular and confluent, sometimes on margins of thalline squamules or in substrate crevices; soredia light greenish grey, without greenish blue pigment. Apothecia zeorine or biatorine, thalline margin thin grey-whitish soon disappearing; own margin concolorous with disc, orange to bright orange, from concave to plane or convex; asci 8-spored; ascospores hyaline, bipolarilocular, widely ellipsoid with wide septum.

Chemistry: Thallus, soralia and soredia if greenish white or greyish white $\mathrm{K}$-, if yellowish $\mathrm{K}+$ violet; apothecia $\mathrm{K}+$ purple.

Ecology: Growing on bark of deciduous trees such as Ulmus, Fraxinus, Tilia, Acer, on steams of steppe and maritime shrubs (Limonium), often in polluted and well-lit conditions, and on limestone. Coppinsiella ulcerosa shows tendency to sea coast distribution, while other taxa are more continental.

Etymology: It is named after the British lichenologist Brian J. Coppins (1949-) (E) (Edinburgh, Scotland) for his great contribution to lichenology and who described the type species of this genus.

Distribution: Eurasia (from Scotland, Southern Scandinavia and Estonia on the north to the Mediterranean regions of Spain to the Caspian Sea coast in the east, and Israel to the south), North Africa, some records known from North America (see special notes) as well as somewhat dubious records from the Southern Hemisphere.

The genus Coppinsiella includes four species, namely Coppinsiella ulcerosa (Coppins et P. James) S. Y. Kondr. et L. Lökös (Northern Hemisphere), C. orbicularis (M. Haji Moniri, Vondrák et Malíček) S. Y. Kondr. et L. Lőkös (Europe), C. substerilis (Vondrák, Palice et van den Boom) S. Y. Kondr. et L. Lőkös (Europe), and a further taxon from North America and from the Austrian Alps, cited by Vondrák et al. (2013) as 'Caloplaca aff. ulcerosa'.

Taxonomic and phylogenetic notes: The species included in the genus Coppinsiella are similar to Caloplaca obscurella (J. Lahm ex Körb.) Th. Fr., but differs from the latter in a film-like thallus (vs. areolate) and dispersed soralia, as well as in growing in lighter habitats. Coppinsiella ulcerosa is easily distinguishable after bright orange apothecia when fertile (not brown or dark brown and $\mathrm{K}$ - as in Caloplaca obscurella).

Species of the genus Coppinsiella may be sometimes mistaken as Scythioria phlogina (Ach.) S. Y. Kondr., Kärnefelt, Elix, A. Thell et J.-S. Hur, but the latter species differs by characters of soralia and soredia. Vondrák suggested a relationship of the Coppinsiella clade (as Caloplaca ulcerosa group) with the genera Athallia and Orientophila in a sister position to species in the genus Orientophila (Vondrák et al. 2017a). After combined dataset of ITS, nr LSU 
and $\mathrm{mtSSU}$ sequences the Coppinsiella branch was found to be positioned in a sister position to the genus Athallia (Vondrák et al. 2017a). Unfortunately in Bayesian phylogeny of Xanthorioideae based on the combined dataset of ITS, mtSSU and nrLSU Orientophila was presented only by simple specimen of still undescribed taxon (mentioned as Orientophila sp.), while molecular data on the type species of genus Orientophila, i.e. Orientophila subscopularis Arup et Frisch, as well as O. loekoesii (S. Y. Kondr. et J.-S. Hur) Arup, Søchting et Frödén are hitherto available. Furthermore data on the type species of genera Orientophila, Ovealmbornia, Athalia, Flavoplaca and other genera of the Xanthorioideae were not included in the phylogenetic analysis.

Unfortunately, authors did not want to clarify the generic status of this group of species, and the new taxon Caloplaca substerilis subsp. orbicularis $\mathrm{M}$. Haji Moniri, Vondrák et Malíček was described within the old genus Caloplaca. However, it is important to emphasise that Vondrák et al. (2017a) have provided nrLSU and mtSSU data for four samples, while ITS data were obtained for a number of specimens of this species group. These data allowed us now to include species of the Caloplaca ulcerosa group in three gene phylogeny provided within our study.

Originally the genus Orientophila was proposed exclusively for two eastern Asian species, i.e. O. subscopularis, type species of the genus, and O. loekoesii (S. Y. Kondr. et J.-S. Hur) Arup, Søchting et Frödén (Arup et al. 2013) However, it became evident that the genus Orientophila includes about 10 species (Kondratyuk et al. 2016, 2017b).

It was also studied here if the Caloplaca ulcerosa group was nested within the Orientophila clade. Molecular data from the type species of all genera of the Xanthorioideae is included in the analysis. The genus Coppinsiella formed a robust monophyletic separate branch in the Athallia-Orientophila clade of the Xanthorioideae from our ITS analysis as well as from combined dataset including all members of the Xanthorioideae (Figs 1-2).

Seawardiella S. Y. Kondr., I. Kärnefelt et A. Thell, gen. nov. MycoBank no.: MB 827055

Similar to the genus Calogaya, but differs in having poorly developed thalline portions, and lacking vegetative propagules.

Type species: Seawardiella lobulata (Flörke) S. Y. Kondr., I. Kärnefelt et A. Thell

Thallus from small rosette-like to indistinct or developed or only as tiny microlobules, irregular at the base of the apothecium, \pm raised above the substrate level, whitish grey or yellowish grey to yellow. Apothecia zeorine to 
biatorine, usually numerous, pronounced, often with a well-developed thalline stipe; disc plane to subconvex; both cortical layers of the thalline exciple and the true exciple paraplectenchymatous. Asci 8-spored. Ascospores hyaline, bipolarilocular, with wide septum.

Chemistry: Thallus if yellowish $\mathrm{K}+$ purple and if not yellowish $\mathrm{K}+$; epihymenium and true exciple $\mathrm{K}+$ purple.

Ecology: It grows on bark of deciduous trees.

Etymology: The name of the new genus honours the British lichenologist and plant ecologist, our close friend and colleague Prof. Mark R. D. Seaward (1938-) to recognise his immense contribution to lichenology and to celebrate his 80th birthday.

Distribution: Widely distributed in both hemispheres.

The genus Seawardiella includes two species, i.e. Seawardia lobulata widely distributed in the Northern Hemisphere and S. tasmaniensis, appears semicryptic and its distribution is still poorly known, but a wide distribution in the Southern Hemisphere is assumed.

Taxonomic and phylogenetic notes: Seawardiella lobulata usually considered to be related to Lazarenkoella polycarpoides and L. persica. However, after combined three gene phylogeny (see Figs 2-3) the latter two taxa belong to the Lazarenkoella monophyletic branch of the Brownlielloideae (see also below description of $S$. tasmaniensis). It should be mentioned that after ITS phylogeny after data of Vondrák et al. (2018) these taxa (Seawardiella lobulata as well as Lazarenkoella polycarpoides and L. persica) belong to different monophyletic branches, too.

A Tasmanian collection of Seawardiella aff. lobulata was selected for describing new species more than 13 years ago. However we were waiting for confirmation of the hypothesis on new species by molecular data. Unfortunately specimens of Seawardiella lobulata is rather poorly represented in European herbaria. Therefore ITS data from only three specimens of Seawardiella lobulata were examined, but recently additional material of $S$. lobulata has been provided by Vondrák et al. (2018). New molecular data indicate that S. lobulata collected in Tasmania seems very unique.

In general Seawardiella lobulata belongs to the so-called the Seawardiella lobulata group (or 'Xanthoria lobulata-Gruppe' sensu Steiner et Poelt 1982). Taxonomy of this group more or less completed after morphological point of view, and these results show good correlation with ITS phylogeny of taxa treated (Vondrák et al. 2018). Totally, the Caloplaca lobulata complex includes Caloplaca lobulata, C. polycarpoides and C. persica, all known from earlier as well as the recently described Caloplaca zoroasteriorum. These four taxa as well as Seawardiella tasmaniensis described here are positioned in distant positions after combined three gene phylogeny, which is discussed below in details (Figs 1-2). 
All species of the former complex Caloplaca lobulata are still more or less nested in the Calogaya clade after ITS phylogeny (Fig. 1). Similar results were shown by Vondrák et al. (2018). However, they made incorrect conclusion that these taxa are members of the genus Calogaya. Unfortunately main portion, i.e. 10 of the 12 species were combined to the genus Calogaya only on the basis of ITS phylogeny by Arup et al. (2013), and the same conclusion was done by Vondrák et al. (2018).

After three gene phylogeny (based on ITS nrDNA, nrLSU and mtSSU sequences) two species (i.e.: Seawardiella lobulata and newly described S. tasmaniensis) are located in the Seawardiella branch of the Xanthorioideae, while three other species (i.e. Lazarenkoella zoroasteriorum, L. persica and L. polycar-

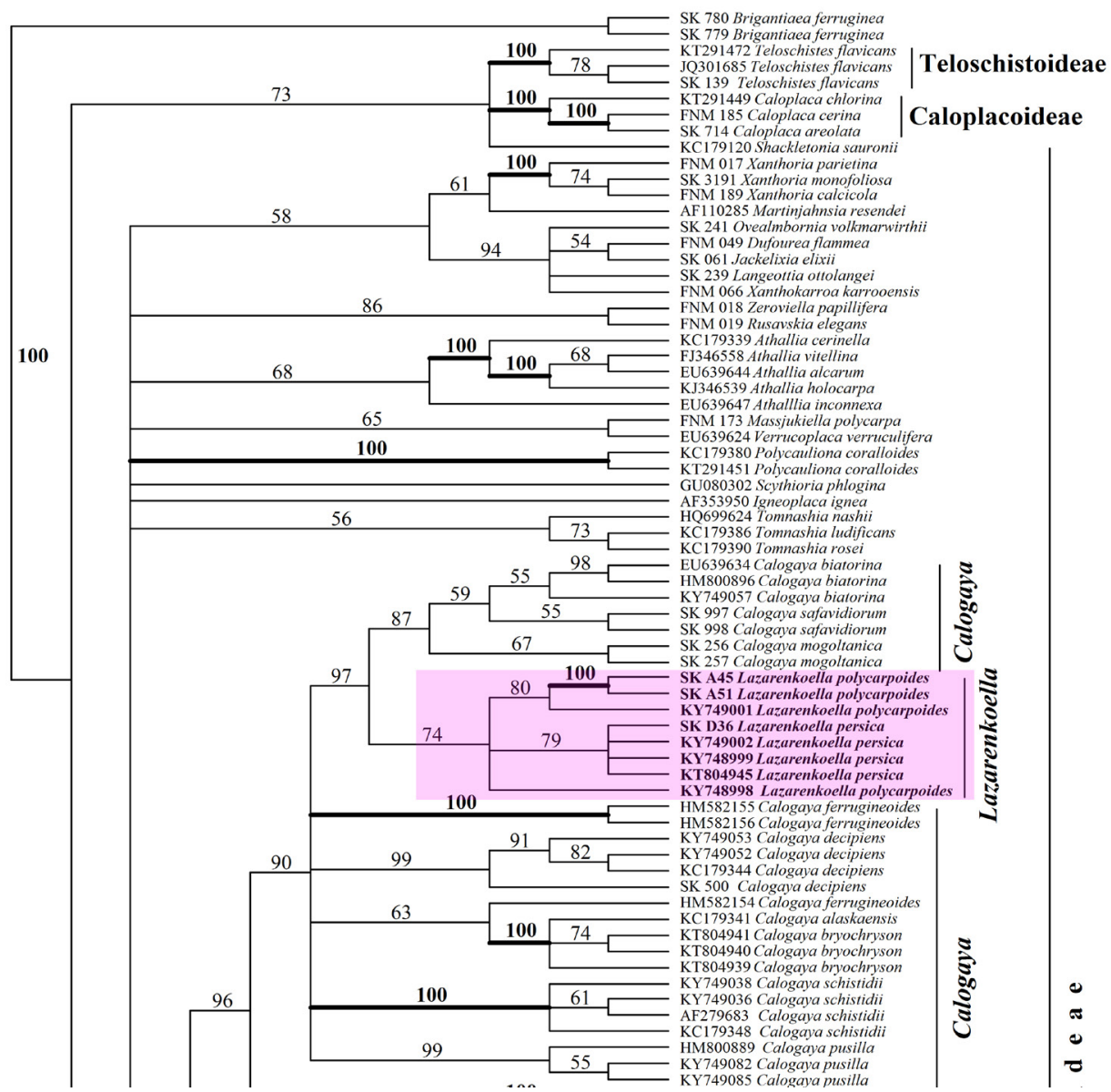

Fig. 1. Phylogenetic analysis of representatives of the subfamily Xanthorioideae after ITS data set 
poides) are positioned in the Lazarenkoella branch of the subfamily Brownlielloideae (Fig. 3).

A final conclusion about position of members of the Calogaya clade after ITS phylogeny can be obtained only when we will have data on ITS nrDNA, nrLSU and mtSSU sequences of all specimens considered to be member of this genus. It is also very important to have results of three gene phylogeny based on data on ITS nrDNA, nrLSU and $\mathrm{mtSSU}$ sequences obtained from the same voucher specimen of all species of the Calogaya clade.



Fig. 1 (continued) 
Thus a general conclusion that position of all species of the Calogaya clade (after ITS phylogeny) should be especially carefully clarified with three gene phylogeny based on data on ITS nrDNA, nrLSU and mtSSU sequences obtained from the same voucher specimen is made.

Seawardiella tasmaniensis S. Y. Kondr., I. Kärnefelt et A. Thell, spec. nova

MycoBank no.: MB 827056

Similar to Seawardiella lobulata, but differs in having an undeveloped thallus consisting only of irregular single microlobules, in having larger and usually solitary

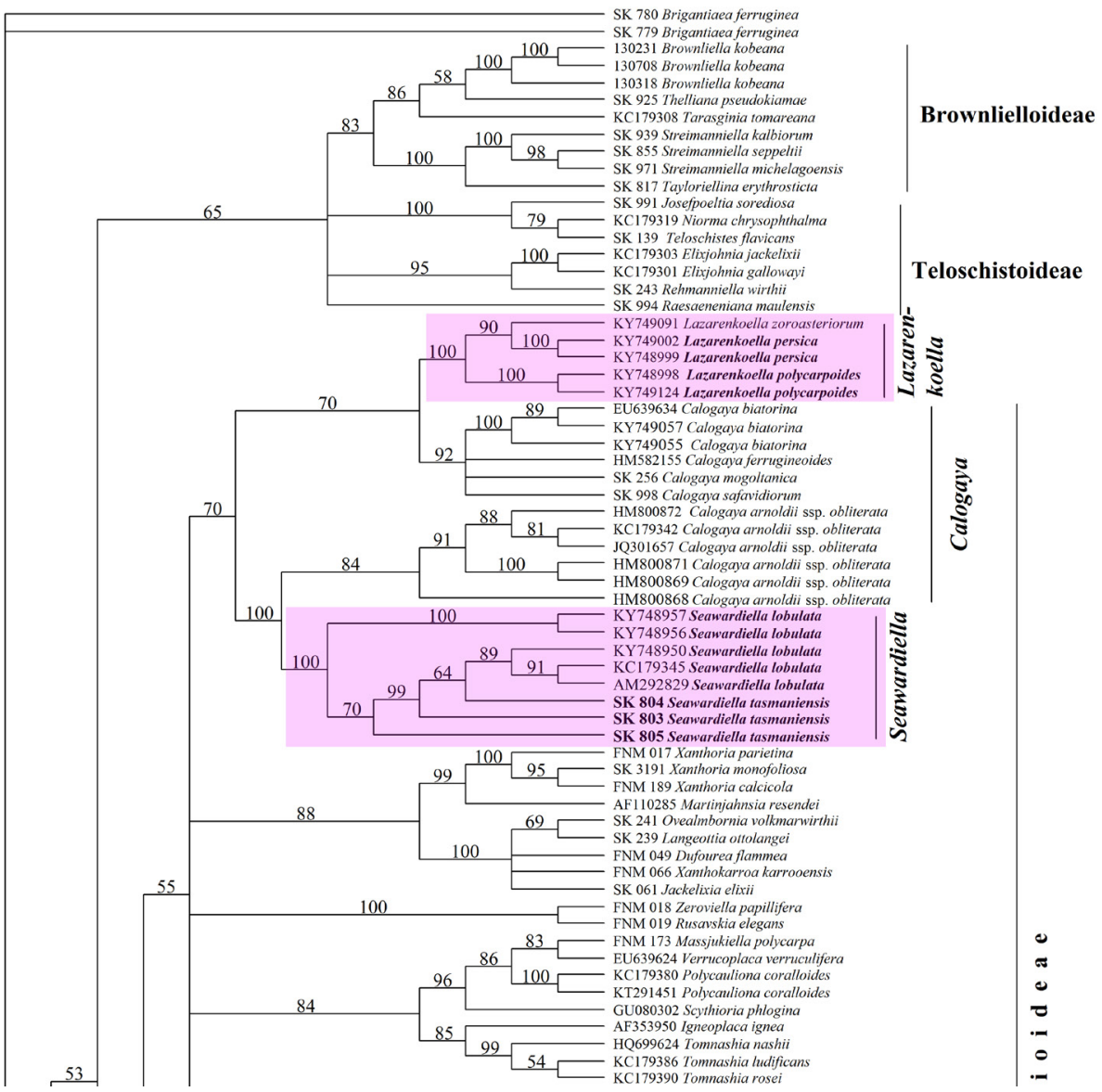

Fig. 2. Phylogenetic analysis of representatives of the subfamily Xanthorioideae after combined data set 
apothecia, soon becoming biatorine, convex and emarginated, as well as in having somewhat shorter ascospores.

Type: Australia, Tasmania, North of Hobart along A1, after Kempton, $1 \mathrm{~km}$ before the turnoff to Oatlands, $42^{\circ} 29.59^{\prime} \mathrm{S}, 147^{\circ} 11.16^{\prime}$ E [elevation is not mentioned], growing on [thick twigs of] Crataegus, locally abundant, Seawardiella tasmaniensis damaged by Muelleriella sp. in places. Coll.: E. I. Kärnefelt (997001), 28.01.1999 (holotype: HO; isotypes: GZU, LD (vouchers SK 803, SK 804, SK 805), KW-L).

Thallus usually not developed or sometimes only as tiny microareoles up to $0.1-0.3 \mathrm{~mm}$ across appear solitary (hardly seen among numerous apothecia of Seawardiella tasmaniensis as well as apothecia of other associated crustose lichens, i.e. Rinodina species and others) or associated at one side of the apothecium stipa, very rarely may form 'rosette-like' aggregation to $0.7-1$



Fig. 2 (continued) 


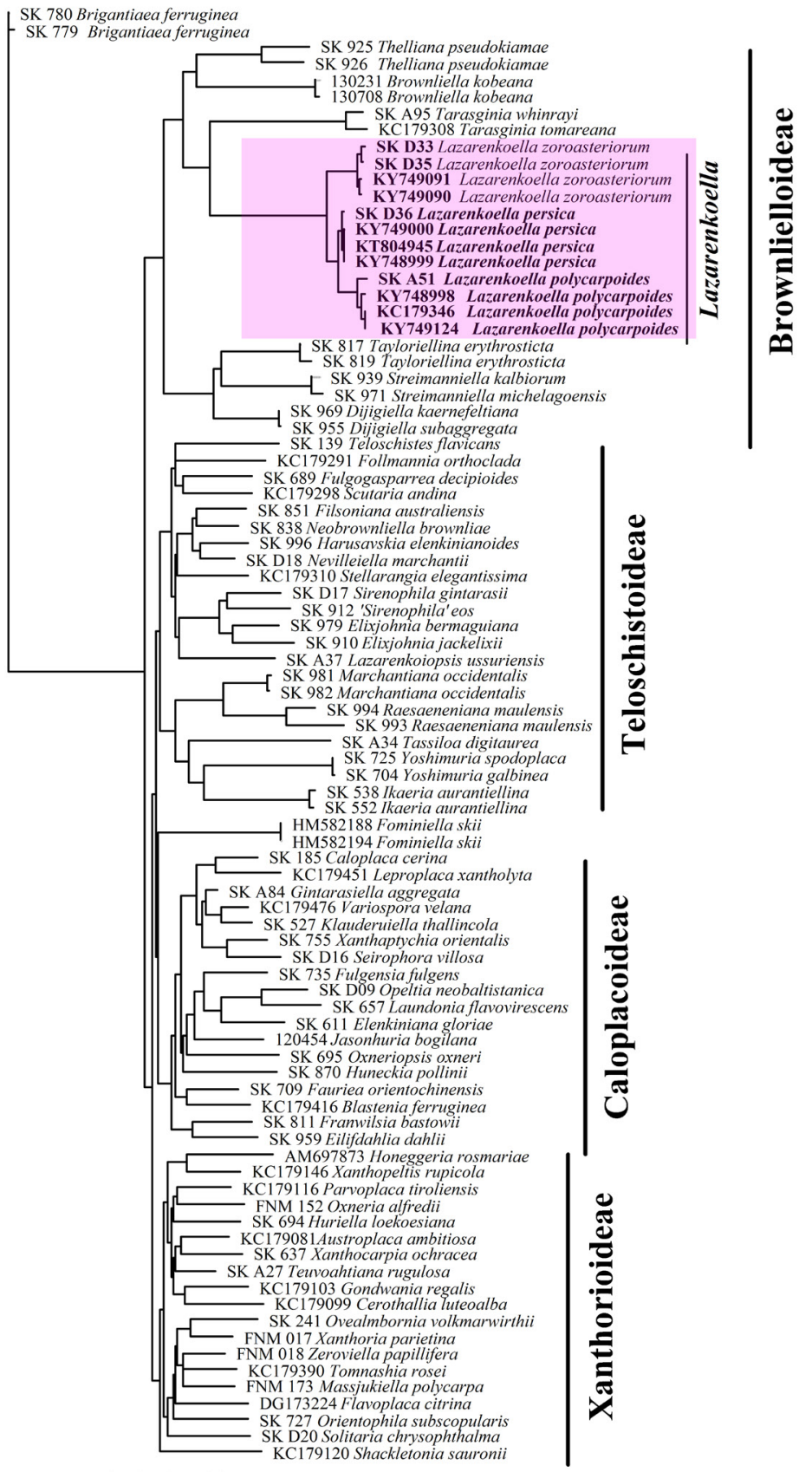

- 0.01 substitutions/site

Fig. 3. Phylogenetic analysis of representatives of the subfamily Brownlielloideae after combined data set 
$\mathrm{mm}$ across around adult apothecia (probably in shaded conditions, i.e. on underside of phorophyte branches), but commonly not distinct; usually only numerous apothecia are well developed. Apothecia 0.3-1.5(-3) $\mathrm{mm}$ diam. [in section to $0.6 \mathrm{~mm}$ thick], numerous, solitary or to densely aggregated per 2-4 or to 10-11 in aggregations, but apothecia aggregations are mainly not correlate with development of thalline areoles; at first (when they are 0.2-0.3 $\mathrm{mm}$ diam.) zeorine or biatorine with distinct yellowish true exciple to $50 \mu \mathrm{m}$ wide, but soon becoming convex to very convex and emarginate, thalline exciple greyish or whitish from the beginning is situated much below of proper margin and then hardly seen as wall of apothecium stipa; in section cortical layer of thalline exciple of very thick walled cells 5-8(-12) $\mu \mathrm{m}$ diam./across; true exciple very thin, $5-7(-12) \mu \mathrm{m}$ thick, (often only $1-2$ cell layer present) or indistinct in basal portion, paraplectenchymatous; hymenium (55-)70-80 $\mu \mathrm{m}$ high; epihymenium brightly light yellow; uppermost cells of the paraphyses distinctly swollen to 6-7 $\mu \mathrm{m}$ diam.; asci 8 -spored; ascospores widely ellipsoid, seem to be elongated owing to rather wide septum, 7-13(-14) $\times 5-7 \mu \mathrm{m}$ in water and (7-)12-13 × (5-)6-7(-7.5) $\mu \mathrm{m}$ in $\mathrm{K}$, septum $(2-) 4-6(-8) \mu \mathrm{m}$ wide in water and (3-)6-8 $\mu \mathrm{m}$ wide in $\mathrm{K}$.

Distribution and ecology: It is known so far only from one single collection from Tasmania, where it was found on bark of thick twigs of Crataegus growing together with the species of the genus Rinodina and other crustose lichens. Kärnefelt (2001) discovered Seawardiella tasmaniensis (as Caloplaca lobulata) in an exposed habitat in open agricultural land growing on twigs and trunks of introduced trees, mainly Crataegus and Populus nigra. In larger parts of Tasmania north of Hobart and along the northern coast this cultivated type of landscape is rather common. The trunks of the well-grown trees were partly covered by both Seawardiella tasmaniensis (as C. lobulata) and also by Xanthoria cf. parietina. Lower partly dead branches were also overgrown by lichens including Seawardiella tasmaniensis (as C. lobulata). Many members of the genera Caloplaca and Xanthoria are favoured by fertilisers from the agricultural land, which can be seen in many European countries. It is strange that Seawardiella tasmaniensis (as C. lobulata) was found in such an abundance in the single Tasmanian locality compared with a quite different situation from European countries.

Etymology: The new species is named after the island where the type locality and single confirmed locality is situated.

Taxonomic notes: A Tasmanian collection labelled Seawardiella aff. lobulata was selected as type material for the new species S. tasmaniensis more than 13 years ago. The present confirmation by molecular data made us confident to describe the new species below. 




Seawardiella tasmaniensis is similar to $S$. lobulata, but differs in having an undeveloped thallus consisting of irregular single microlobules only, to $0.3 \mathrm{~mm}$ across compared with the microrosette-like thallus of S. lobulata measuring $2-3(-5) \mathrm{mm}$ diam./ across, surrounded by $0.4-0.9 \mathrm{~mm}$ large thallus portions. Furthermore, the new species differs in having larger and usually solitary apothecia $(0.3-1.5(-3) \mathrm{mm}$ diam., solitary vs. $0.2-0.6 \mathrm{~mm}$ diam., $4-9$ per thalline rosettes in S. lobulata). The apothecia of $S$. tasmaniensis soon becomes biatorine, convex and emarginated compared to lecanorine with a permanent thalline margin in S. lobulata. Finally, S. tasmaniensis differs by somewhat shorter ascospores, 7-13 $\mu \mathrm{m}$ vs. 10-16 $\mu \mathrm{m}$ long in S. lobulata (see also Table 2) (Kondratyuk et al. 2004).

Seawardiella tasmaniensis exists first of all as apothecia. A thallus is not present in all cases - or not seen - whereas a regular rosette-like thallus always surrounds the apothecia of Caloplaca lobulata. Furthermore, Caloplaca lobulata is characterised by having plane and regularly rounded discs with well-developed permanent thalline margins usually seen in all adult apothecia. Interestingly, European material of Seawardiella lobulata is never damaged by Muelleriella, while the entire material of $S$. tasmaniensis was \pm damaged.

Molecular data confirm several taxa within the S. lobulata complex, of which a Tasmanian species is described here. Seawardiella tasmaniensis is without any doubts close to C. lobulata reminding of the latter's ability to form a microthallus. The new species is confirmed in the molecular phylogeny based on ITS1/ITS2 nrDNA, 28S nrLSU and $12 \mathrm{~S} \mathrm{mtSSU}$ (Figs 1-2). 


\section{New combinations}

Athallia inconnexa (Nyl.) S. Y. Kondr. et L. Lőkös, comb. nova - MycoBank no.: MB 827519 - Basionym: Lecanora inconnexa Nyl., Flora, Regensburg 66: 100 (1883) E Caloplaca inconnexa (Nyl.) Zahlbr., Cat. Lich. Univers. 7: 145 (1930)[1931].

Calogaya safavidiorum (S. Y. Kondr.) S. Y. Kondr. et L. Lőkös, comb. nova - MycoBank no.: MB 827520 - Basionym: Caloplaca safavidiorum S. Y. Kondr., in Kondratyuk, Lőkös, Zarei-Darki et Hur, Acta bot. hung. 54(3-4): 325 (2012).

Coppinsiella orbicularis (M. Haji Moniri, Vondrák et Malíček) S. Y. Kondr. et L. Lőkös, stat. et comb. nova - MycoBank no.: MB 827063 - Basionym: Caloplaca substerilis subsp. orbicularis M. Haji Moniri, Vondrák et Malíček, in Vondrák et al., Nordic J. Bot. 35(3): 370 (2017). - Note: One more taxon mentioned as Caloplaca aff. ulcerosa (Vondrák et al. 2013) is still waiting for legal describing.

Coppinsiella substerilis (Vondrák, Palice et van den Boom) S. Y. Kondr. et L. Lőkös, comb. nova - MycoBank no.: MB 827057 - Basionym: Caloplaca substerilis Vondrák, Palice et van den Boom, in Vondrák et al., Lichenologist 45(6): 715 (2013).

Coppinsiella ulcerosa (Coppins et P. James) S. Y. Kondr. et L. Lőkös, comb. nova - MycoBank no.: MB 827058 - Basionym: Caloplaca ulcerosa Coppins et P. James, Lichenologist 11(2): 139 (1979).

Lazarenkoella persica (J. Steiner) S. Y. Kondr. et L. Lőkös, comb. nova MycoBank no.: MB 827059 - Basionym: Xanthoria polycarpoides var. persica J. Steiner, Annls mycol. 8(2): 241 (1910) $\equiv$ Caloplaca persica (J. Steiner) M. Steiner et Poelt, Pl. Syst. Evol. 140(2-3): 168 (1982) झ Xanthoria persica (J. Steiner) Szatala, (1957) $\equiv$ Calogaya persica (J. Steiner) Arup, Frödén et Søchting, Nordic J. Bot. 31(1): 39 (2013).

Lazarenkoella polycarpoides (J. Steiner) S. Y. Kondr. et L. Lőkös, comb. nova-MycoBank no.: MB 827060 - Basionym: Xanthoria polycarpoides J. Steiner, Annls mycol. 8(2): 241 (1910) = Caloplaca polycarpoides (J. Steiner) M. Steiner et Poelt, Pl. Syst. Evol. 140(2-3): 168 (1982) $\equiv$ Calogaya polycarpoides (J. Steiner) Arup, Frödén et Søchting, Nordic J. Bot. 31(1): 39 (2013).

Notes on the genus Lazarenkoella: Thanks to recent molecular data from Calogaya polycarpoides, C. persica and Lazarenkoella zoroasteriorum it became possible to delimit the genus Lazarenkoella more clearly. Two specimens, SK D36 and SK D35, cited as Lazarenkoella aff. zoroasteriorum by Kondratyuk et al. (2015a), in fact represents Calogaya polycarpoides and C. persica, respectively. The new combinations $L$. polycarpoides and $L$. persica are proposed here. The genus Lazarenkoella was positioned as a monophyletic branch in sister position to Calogaya in the subfamily Xanthorioidae in the study by Vondrák et al. 
(2018). However, when adding representatives from all the four subfamilies of the Teloschistaceae, Lazarenkoella forms a monophyletic branch within the subfamily Brownlielloideae (Fig. 3). The combinations Lazarenkoella polycarpoides and L. persica should be confirmed in the future in molecular analyses, preferably based on the same three genes used in this study, and from the vouchers cited by Vondrák et al. (2018).

Seawardiella lobulata (Flörke) S. Y. Kondr., I. Kärnefelt et A. Thell, comb. nova - MycoBank no.: MB 827061 - Basionym: Lecanora lobulata Flörke, Mag. Neuesten Entdeck. Gesammten Naturf. Freunde Berlin 1: 219 (1820) $\equiv$ Xanthoria lobulata (Flörke) B. de Lesd., Bull. Soc. bot. Fr. 54: 282 (1907) झ Calogaya lobulata (Flörke) Arup, Frödén et Søchting, Nordic J. Bot. 31(1): 39 (2013) = Xanthoria boulyi Zahlbr., Lich. rarior. exsicc., no. 119 (1909).

\section{CONCLUSIONS}

The new genera Coppinsiella and Seawardiella enlarged the number of genera in the Xanthorioideae to 41. The genus Coppinsiella includes three species earlier included in the Caloplaca ulcerosa group. The genus Seawardiella includes two species from the former 'Caloplaca' lobulata aggregation ('Xanthoria lobulata-Gruppe' sensu Steiner et Poelt 1982), i.e. Seawardiella lobulata and the recently described S. tasmaniensis.

Three other species from the former 'Caloplaca' lobulata aggregation (i.e. Lazarenkoella zoroasteriorum, L. persica and L. polycarpoides) are positioned in the Lazarenkoella branch of the Brownlielloideae based on ITS nrDNA, nrLSU and $\mathrm{mtSSU}$ sequences, while they are still positioned in the Calogaya clade after ITS phylogeny or if a limited number of taxa are included in the phylogenetic analysis of the Teloschistaceae.

Acknowledgements - We are thankful to Dr E. Farkas (Vácrátót, Hungary) for the valuable comments on manuscript, to Dr Konstanze Bensch (the MycoBank team, UK) for nomenclature comments, and to Drs J. Kim, M. H. Yu, M.-H. Jeong, and S.-H. Jang (KoLRI, Sunchon, South Korea) for providing molecular data on a number of taxa of genera considered in this paper.

\section{REFERENCES}

Arup, U., Søchting, U. and Frödén, P. (2013): A new taxonomy of the family Teloschistaceae. - Nordic J. Bot. 31: 16-83. https://doi.org/10.1111/j.1756-1051.2013.00062.x 
Fedorenko, N. M., Stenroos, S., Thell, A., Kärnefelt, I. and Kondratyuk, S. Y. (2009): A phylogenetic analysis of xanthorioid lichens (Teloschistaceae, Ascomycota) based on ITS and mtSSU sequences. - Bibl. Lichenol. 100: 49-84.

Fedorenko, N. M., Stenroos, S., Thell, A., Kärnefelt, I., Elix, J. A., Hur, J. S. and Kondratyuk, S. Y. (2012): Molecular phylogeny of xanthorioid lichens (Teloschistaceae, Ascomycota), with notes on their morphology. - Bibl. Lichenol. 108: 45-64.

Gardes, M. and Bruns, T. D. (1993): ITS primers with enhanced specificity for basidiomycetes - application to the identification of mycorrhizae and rusts. - Mol. Ecol. 2: 113118. https://doi.org/10.1111/j.1365-294x.1993.tb00005.x

Kärnefelt, I. (2001): Caloplaca lobulata occurring in Tasmania. - Mycotaxon 80: 461-464.

Kondratyuk, S. Y. (2004): Oxneria, Rusavskia, Teloschistes, Xanthoanaptychia, Xanthomendoza, Xanthoria. - In: Andreev, M. P. and Roms, E. G. (eds): Handbook of the lichens of Russia. 9. Fuscideaceae, Teloschistaceae. Nauka, Sankt-Peterburg, pp. 37-38, 242-302.

Kondratyuk, S. Y., Khodosovtsev, O. Y. and Oxner, A. N. (2004): Caloplaca. - In: Andreev, M. P. and Roms, E. G. (eds): Handbook of the lichens of Russia. 9. Fuscideaceae, Teloschistaceae. Nauka, Sankt-Peterburg, pp. 38-236.

Kondratyuk, S. Y., Kärnefelt, I., Thell, A., Elix, J. A., Kim, J., Jeong, M. H., Yu, N. H., Kondratiuk, A. S. and Hur, J.-S. (2014): A revised taxonomy of the subfamily Xanthorioideae (Teloschistaceae, Ascomycota) based on molecular phylogeny. - Acta Bot. Hung. 56: 141-178. https:// doi.org/10.1556/abot.56.2014.1-2.12

Kondratyuk, S. Y., Kärnefelt, I., Thell, A., Elix, J. A., Kim, J., Kondratiuk, A. S. and Hur, J.-S. (2015a): Brownlielloideae, a new subfamily in the Teloschistaceae (Lecanoromycetes, Ascomycota). - Acta Bot. Hung. 57: 321-341. https:// doi.org/10.1556/034.57.2015.3-4.6

Kondratyuk, S. Y., Kim, J. A., Yu, N.-H., Jeong, M.-H., Jang, S. H., Kondratiuk, A. S., Zarei-Darki, B. and Hur, J.-S. (2015b): Zeroviella, a new genus of xanthorioid lichens (Teloschistaceae, Ascomycota) proved by three gene phylogeny. - Ukr. Bot. J. 72(6): 574-584. https:// doi.org/10.15407/ukrbotj72.06.574

Kondratyuk, S. Y., Lőkös, L., Kärnefelt, I., Thell, A., Elix, J. A., Oh, S.-O. and Hur, J.-S. (2016): Three new Orientophila species (Teloschistaceae, Ascomycota) from Eastern Asia. - Graphis Scripta 28(1-2): 50-58.

Kondratyuk, S. Y., Lőkös, L., Upreti, D. K., Nayaka, S., Mishra, G. K., Ravera, S., Jeong, M.-H., Jang, S.-H., Park, J.-S. and Hur, J.-S. (2017a): New monophyletic branches of the Teloschistaceae (lichen-forming Ascomycota) proved by three gene phylogeny. Acta Bot. Hung. 59(1-2): 71-136. https://doi.org/10.1556/ 034.59.2017.1-2.6

Kondratyuk, S. Y., Lőkös, L., Halda, J. P., Roux, C., Upreti, D. K., Schumm, F., Mishra, G. K., Nayaka, S., Farkas, E., Park, J. S., Lee, B. G., Liu, D., Woo, J.-J. and Hur, J.-S. (2017b): New and noteworthy lichen-forming and lichenicolous fungi 6. - Acta Bot. Hung. 59(1-2): 137-260. https://doi.org/10.1556/ 034.59.2017.1-2.7

Kondratyuk, S., Persson, P.-E., Hansson, M., Mishra, G. K., Nayaka, S., Liu, D., Hur, J.-S. and Thell, A. (2018a): Upretia, a new caloplacoid lichen genus (Teloschistaceae, lichen-forming Ascomycota) from India. - Cryptogam Biodiversity and Assessment, Spec. Vol., e-ISSN: 2456-0251, pp. 22-31.

Kondratyuk, S. Y., Persson, P.-E., Hansson, M., Lőkös, L., Liu, D., Hur, J.-S., Kärnefelt, I. and Thell, A. (2018b): Hosseusiella and Rehmanniella, two new genera in the Teloschistaceae. - Acta Bot. Hung. 60(1-2): 89-113. https://doi.org/10.1556/034.60.2018.1-2.7

Swofford, D. L. (2003): PAUP*, Phylogenetic analysis using parsimony (*and other methods). Sunderland, Sinauer Associates, Massachusetts. 
Vilgalys, R. and Hester, M. (1990): Rapid genetic identification and mapping of enzymatically amplified ribosomal DNA from several Cryptococcus species. - J. Bacteriol. 172(8): 4238-4246. https://doi.org/10.1128/jb.172.8.4238-4246.1990

Vondrák, J., Soun, J., Arup, U., Aptroot, A. and Redchenko, O. (2009): Caloplaca ulcerosa, a maritime species in Europe with a remarkable occurrence in the Czech Republic. Bryonora 44: 1-7.

Vondrák, J., Frolov, I., Ríha, P., Hrouzek, P., Palice, Z., Nadyeina, O., Halıcı, G., Khodosovtsev, A. and Roux, C. (2013): New crustose Teloschistaceae in central Europe. Lichenologist 45: 701-722. https://doi.org/10.1017/s0024282913000455

Vondrák, J., Haji Moniri, M., Malíček, J. and Košnar, J. (2017a): Extensive yellow crusts below limestone overhangs: a new taxon close to a minute epiphytic lichen. - Nordic J. Bot. 35: 368-376. https://doi.org/10.1111/njb.01371

Vondrák, J., Ismaylov, A. and Urbanavichus, G. (2017b): Lichens of the family Teloschistaceae: an eastern part of the Caucasian biodiversity hot-spot. - Nova Hedwigia 104(4): 483-498. https://doi.org/10.1127/nova_hedwigia/2016/0387

Vondrák, J., Shahidin, H., Haji Moniri, M., Halıcı, G. and Košnar, J. (2018): Taxonomic and functional diversity in Calogaya (lichenised Ascomycota) in dry continental Asia. Mycol. Progress 17: 897-916. https://doi.org/10.1007/s11557-018-1402-9

Zoller, S., Scheidegger, C. and Sperisen, C. (1999): PCR primers for the amplification of mitochondrial small subunit ribosomal DNA of lichen-forming ascomycetes. - $\mathrm{Li}$ chenologist 31: 511-516. https://doi.org/10.1017/s0024282999000663 